
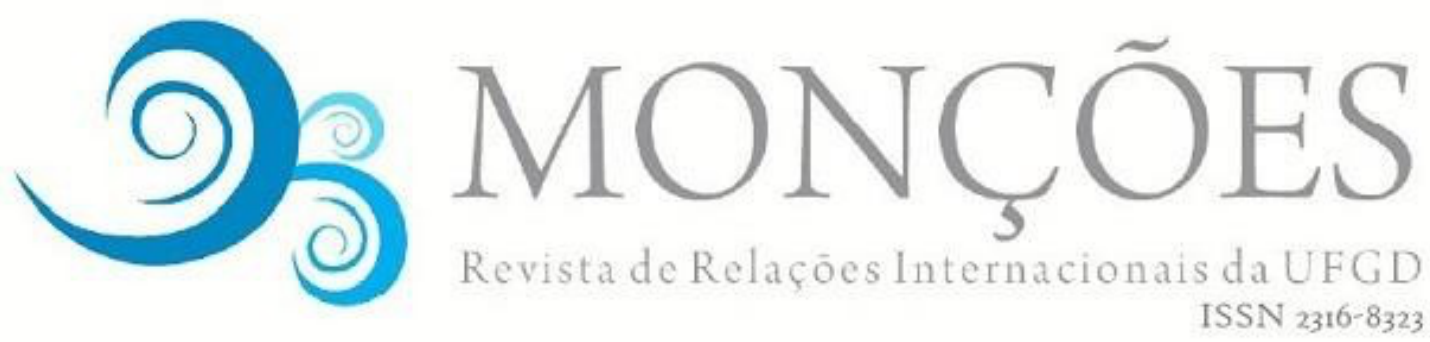

\title{
NATUREZA E CARACTERÍSTICAS DAS COMISSÕES ECONÔMICAS DAS NAÇÕES UNIDAS: A ESPECIFICIDADE DA CEPAL
}

\author{
NIEMEYER ALMEIDA FILHO \\ Universidade Federal de Uberlândia (UFU), Instituto de Economia e Relações \\ Internacionais da UFU. Uberlândia, MG, Brasil. \\ ORCID: https://orcid.org/0000-0003-2421-4890 \\ niemeyerfilho@hotmail.com
}

Resumo: O artigo discute as circunstâncias de criação das cinco comissões econômicas da ONU, procurando apreender tanto o contexto histórico quanto as características de cada uma delas. A hipótese é que as condições históricas de criação da CEPAL abriram a possibilidade de especificidades muito relevantes ao debate sobre desenvolvimento econômico nos anos 1950 na América Latina, e na Europa e América do Norte. A CEPAL tem contribuições inscritas como heterodoxas no âmbito das teorias de desenvolvimento, engendrando uma característica de Escola de Pensamento que está ausente nas demais comissões.

Palavras-chave: comissões econômicas da ONU; natureza das comissões econômicas da ONU; políticas de desenvolvimento na América Latina; CEPAL.

\section{NATURE AND CHARACTERISTICS OF THE UNITED NATIONS ECONOMIC COMMISSIONS: THE SPECIFICITY OF ECLAC}

\begin{abstract}
The article discusses the circumstances of creation of the five UN economic committees, seeking to apprehend both the historical context and the characteristics of each of them. The hypothesis is that the historical conditions of creation of ECLAC opened the possibility of specificities very relevant to the debate on economic development of the 1950s in Latin America, and Europe and North America. ECLAC has contributions entered as heterodox in the context of development theories, engendering a characteristic of School of Thought that is absent in the other committees.

Keywords: UN economic commissions; nature of UN economic commissions; development policies in Latin America; ECLAC.

\section{NATURALEZA Y CARACTERÍSTICAS DE LAS COMISIONES ECONÓMICAS DE LAS NACIONES UNIDAS: LA ESPECIFICIDAD DE LA CEPAL}

Resumen: El artículo analiza las circunstancias de la creación de las cinco comisiones económicas de la ONU, buscando captar tanto el contexto histórico como las características de cada una de ellas. La hipótesis es que las condiciones históricas para la creación de la CEPAL abrieron la posibilidad de especificidades muy relevantes para el debate sobre el desarrollo económico en la década de 1950 en América Latina, Europa y América del Norte. La CEPAL tiene aportes registrados como heterodoxos en el ámbito de las teorías del desarrollo, generando una característica de Escuela de Pensamiento que está ausente en otros comités.

Palabras chave: comisiones económicas de la ONU; naturaleza de las comisiones económicas de la ONU; políticas de desarrollo en América Latina; CEPAL. 


\section{Introdução}

O estudo conjunto das comissões regionais da ONU é pouco frequente na literatura especializada, tanto de Relações Internacionais quanto de Economia. $\mathrm{Na}$ América Latina e no Brasil, há expressiva produção bibliográfica sobre a CEPAL, contudo, muito associada a recomendações de políticas de desenvolvimento que a comissão formulou nos anos 1950 e nos anos 1990. Esses foram períodos de intenso debate ideológico no âmbito da ONU e de seus órgãos especializados na regulação e recomendação de políticas econômicas e de desenvolvimento.1 $\mathrm{O}$ destaque para a CEPAL tem a ver com o papel que a comissão cumpriu na América Latina nos seus primeiros anos de existência.

Há cinco comissões econômicas na ONU, todas elas vinculadas ao Conselho de Desenvolvimento Econômico e Social (ECOSOC): a Comissão Econômica para Europa (ECE) e a Comissão Econômica para Ásia e o Pacífico (ESCAP)2 foram as primeiras a serem criadas em 1947, seguidas da Comissão Econômica para a América Latina (CEPAL) em 1948; Comissão Econômica para a África (ECA) em 1958; e Comissão Econômica e Social para a Ásia Ocidental (ESCWA) em 1973.

Essas comissões, embora aparentem ser diferenciadas apenas pela região de localização e abrangência, apresentam circunstâncias históricas e naturezas distintas. A ECE e ESCAP foram criadas por recomendação da Assembleia Geral para servir de instrumento ao processo de reconstrução das regiões devastadas pela guerra, embora tenham cumprido funções limitadas em relação a isto, muito mais relacionadas a acordos de cooperação em infraestrutura e normas internacionais. Ainda que a CEPAL também tenha sido recomendada pela Assembleia Geral, ela foi criada por proposição de governos dos países latino-americanos, que se sentiram indevidamente excluídos do esforço de reconstrução e aceleração do desenvolvimento no Pós Segunda Guerra Mundial. Posteriormente, tanto a ECA

\footnotetext{
${ }^{1}$ Aqui estamos tratando essas políticas como distintas, pois esta é a característica da fase que se abre nos anos 1990. As políticas de desenvolvimento, no âmbito supranacional, têm grande identidade com o que na literatura da Economia denomina-se de Teorias e Políticas de Crescimento Econômico. Nos anos 1950, o conteúdo das proposições de desenvolvimento era significativamente mais amplo, pois o objeto delas era as economias tidas como subdesenvolvidas ou atrasadas.

${ }^{2}$ A sigla original de criação era ESCAFE - Economic Commission for Asia and Far East. Em 1974, o nome foi mudado para ESCAP - Economic Commission for Asia and Pacific.
} 
quanto ESCWA foram criadas por recomendação da Assembleia Geral para estimular o desenvolvimento econômico em regiões consideradas sensíveis social e politicamente. Ressalve-se que no caso da ECA houve igualmente reinvindicação de países da região, embora conjugada com apoio das antigas metrópoles. Contudo, a CEPAL destaca-se das demais por ser a única das cinco agências criada exclusivamente por reinvindicação regional, sem vínculo direto com os interesses hegemônicos colocados no centro da Assembleia Geral.

O objetivo mais geral do presente artigo é estimular o estudo conjunto dessas comissões econômicas, por considerá-las importantes espaços de difusão de posições da ONU. O objetivo mais específico é mostrar que nesse contexto o papel da CEPAL é um pouco mais abrangente, firmando-se como um órgão técnico de contribuições à teoria e à política de desenvolvimento.

Nossa hipótese é que a CEPAL tem natureza diversa das outras comissões regionais, justo pelas circunstâncias e forma de implementação. A CEPAL chegou a cumprir funções de ESCOLA DE PENSAMENTO nas duas primeiras décadas de sua existência, contestando ou requalificando proposições do mainstream das teorias e políticas de desenvolvimento formuladas na Europa e América do Norte nos anos 1950. Este período inicial foi importante o suficiente para influenciar sua trajetória nos setenta anos de existência, completados em 2018. Ainda hoje é possível observar aspectos da ação institucional da CEPAL significativamente distintos das demais comissões.

O artigo está dividido em duas seções, além desta introdução. Na primeira delas, tratamos das circunstâncias e forma de criação das três primeiras comissões regionais da ONU. Há ainda apontamentos das circunstâncias de criação das outras duas comissões, ECA e ESCWA, embora com muito menos elementos, dadas as dificuldades de documentação e bibliografia. Na segunda seção, concentramo-nos em mostrar as determinações das especificidades da CEPAL. Finalmente, apresentamos algumas notas conclusivas. 


\section{Comissões econômicas regionais: circunstâncias históricas de criação e missões institucionais}

Segundo Tony Judt (2007, especialmente cap. 1), as condições econômicas e sociais do imediato pós-guerra (primeiros dois anos) foram socialmente dramáticas na Europa. Um número importante de países não dispunha de condições de oferta de alimentos suficientes para garantir a quantidade mínima de calorias necessárias à reprodução da vida humana. Ademais havia significativa destruição dos aparatos produtivos, não apenas das fábricas, mas da infraestrutura necessária à produção e distribuição de mercadorias.

A descrição da situação da Europa, segundo Tony Judt, pode ser resumida pela seguinte passagem:

Na sequência da Segunda Guerra Mundial, a perspectiva da Europa era de miséria e desolação total. Fotografias e documentários da época mostram fluxos patéticos de civis impotentes atravessando paisagens arrasadas, com cidades destruídas e campos áridos. Crianças órfãs perambulam melancólicas, passando por grupos de mulheres exaustas que reviram montes de entulho. Deportados e prisioneiros de campos de concentração, com as cabeças raspadas e vestindo pijamas listrados, fitam a câmera, com indiferença, famintos e doentes. Até os bondes parecem traumatizados - impulsionados por corrente elétrica intermitente, aos trancos, ao longo de trilhos danificados. Tudo e todos - exceto as bem nutridas forças aliadas de ocupação - parecem surrados, desprovidos de recursos, exauridos (JUDT, 2007, p. 27).

Esta situação dramática não foi suficiente para esforço internacional de cooperação nos moldes do que ocorreu ao longo do período da guerra. Ademais, como ocorreram significativos fluxos migratórios ao longo do período do conflito, houve repatriação de indivíduos para os países de origem, sem preocupação específica com a gravidade da situação social. Isto porque a Segunda Guerra Mundial foi basicamente um confronto de exércitos de homens, a maior parte deles em idade ativa plena, de modo que os fluxos migratórios foram de mulheres, crianças e idosos. Ao retornar aos seus países de origem, muitos deles com economias débeis 
economicamente e sem condição de oferta de emprego, tampouco de apoio do Estado, esses indivíduos viveram situação grave de penúria.

A princípio a política externa americana não se responsabilizou por apoios diretos, ficando apenas na condição privilegiada de nação distante do palco do conflito e em condições de suprir o restante do mundo das mercadorias e dos serviços necessários ao processo de reconstrução da Europa e parte da Ásia. Evidentemente, essa posição era ética e politicamente insustentável e foi alterada pela proposição do Plano Marshall em 1947.

Este foi um plano muito diferente do que seria de se esperar se observássemos a prática de cooperação econômica e apoio existentes até então. O plano foi engenhoso em criar novas formas de apoio que viabilizaram, rapidamente, a reconstrução da Europa.

As propostas de Marshall configuravam, nitidamente, um rompimento com práticas passadas. Para começar, exceto por certas disposições, ficaria a critério dos europeus a decisão de aceitar auxílio norteamericano e como emprega-lo, ainda que conselheiros e especialistas norte-americanos desempenhassem papel de destaque na gestão dos recursos. Em segundo lugar, o auxílio deveria se estender durante alguns anos sendo, portanto, desde o início, um programa estratégico de recuperação e crescimento, e não um fundo emergencial de desastre. Em terceiro lugar, os montantes em questão eram de fato substanciosos. Quando, em 1952, a Ajuda Marshall chegou ao fim, os Estados Unidos haviam gasto cerca de 13 bilhões de dólares, mais do que a soma de todo o auxílio internacional previamente oferecido pelo país. O Reino Unido e a França receberam as quantias mais elevadas, em termos absolutos, mas é provável que o impacto relativo na Itália e nos receptores menores tenha sido ainda maior: na Áustria, durante o primeiro ano do Programa de Recuperação Europeia (PRE), de julho de 1948 a junho de 1949, 14\% da receita nacional vieram da Ajuda Marshall. Esses valores eram vultosos para a época: em termos de recursos em caixa, o PRE representava o equivalente a cerca de 100 bilhões de dólares em valores atuais (2004), mas como uma porcentagem equivalente do Produto Interno Bruto norte-americano (entre 1948-1951), o plano consumia cerca de $0,5 \%$ do PIB, um Plano 
Marshall do início do século XXI iria custar em torno de 201 bilhões de dólares (JUDT, 2007, p. 105).

A princípio, o Plano Marshall estava aberto a todos os países que participaram do esforço direto de guerra e careciam de apoio para reconstrução. Todavia, os confrontos políticos internos ao bloco dos Aliados, sobretudo o confronto EUA/URSS, logo mostraram a inviabilidade de coexistência de planos econômicos inspirados por diferentes ideologias. O discurso da unidade mundial em torno de uma convivência pacífica mostrou-se uma névoa a encobrir as tensões entre as duas potências cujas diretrizes de desenvolvimento partiam de modelos de sociedades muito diferentes. $A$ Guerra Fria que dali em diante se estabeleceu fez com que instituições internacionais fossem palco de constante disputa.

Não cabe aqui discutir essas condições específicas, já muito bem apreendidas por historiadores (HOBSBAWN, 1994; JUDT, 2007). O ponto é que a Guerra Fria disseminou um conflito ideológico, político, militar para diferentes espaços geográficos, ganhando forte conotação geopolítica. As regiões não representavam exatamente o mesmo que no período anterior à Primeira Guerra Mundial, em que a ocupação dos territórios tinha clara função econômica de controle direto de riquezas, mas tinham igual importância estratégica de fortalecer um bloco político em relação ao outro.

Portanto, a ausência da URSS do Plano Marshall, além da recomendação de que seus aliados subordinados ficassem de fora, mostra as dificuldades de relação entre países membros dos dois blocos. Neste contexto, parece-nos que as comissões regionais foram espaços onde a cooperação interessava a ambos os blocos e em atividades que não apresentavam forte conotação estratégica geopolítica. Esta, parece-nos, foi a função inicial das comissões regionais da Europa (ECE) e da Ásia Pacífico (ESCAP). Mesmo assim, como veremos mais à frente, essas duas comissões e a CEPAL foram a princípio criadas como órgãos emergenciais, não permanentes.

A criação da CEPAL seguiu outra racionalidade, nascendo de uma iniciativa diplomática individual, que depois foi acompanhada pela maior parte das representações diplomáticas dos países da região. Contudo, na descrição histórica que há no âmbito das próprias comissões não há realce para esta característica. $A$ referência que se pode obter no site da ECE, por exemplo, destaca datas, mas não 
especificidades, pois oficialmente todas as cinco comissões cumprem o mesmo desiderato de fomentar a cooperação econômica pró desenvolvimento econômico e social.

O estabelecimento de uma Comissão Econômica para a Europa foi recomendado pela "Subcomissão temporária para a reconstrução econômica das zonas devastadas", convocada em Londres em 29 de julho de 1946 e informado o Conselho Económico e social em 13 de setembro 1946. Em 11 de dezembro de 1946, a Assembleia Geral das Nações Unidas, na sua quinquagésima quinta reunião plenária, recomendou por unanimidade, "a fim de dar uma ajuda eficaz aos países devastados pela guerra, o Conselho Econômico e Social, na sua próxima sessão, a dar alerta e consideração favorável à criação de uma Comissão Econômica para a Europa ". O Conselho, na sua quarta sessão, cumpriu os desejos da Assembleia Geral, adoptando, em 28 de março de 1947, a resolução 36 (IV) que estabelece a ECE e Ihe dá os seus termos de referência. A Comissão Econômica para a Europa foi, assim, juntamente com a Comissão Econômica para a Ásia e o Extremo Oriente (ECAFE), que foi estabelecida na mesma data, uma das duas primeiras comissões econômicas regionais a ser estabelecida pelo Conselho. Posteriormente, o Conselho estabeleceu a Comissão Econômica para a América Latina (ECLA), em março de 1948, a Comissão Econômica para África (ECA), em abril de 1958, e a Comissão Econômica para a Ásia Ocidental (ECWA), em agosto de 1973. Durante os primeiros quatro anos após a sua fundação, a ECE funcionou numa base provisória: o Conselho expressamente forneceu uma revisão especial do trabalho da Comissão, a realizar-se o mais tardar em 1951, "com vista a determinar se a Comissão deveria ser cessada ou continuada, e se continuada, que modificações, se houver, devem ser feitas em seus termos de referência" (UNECE, 2020, tradução livre $)^{3}$.

Esses aspectos em comum e também algumas diferenças podem ser visualizadas nas resoluções de criação das comissões (disponíveis no Repositório da ONU). É nítido o caráter complementar e subsidiário da ECE e ESCAP ao Plano Marshall em comparação à CEPAL, cujo propósito é basicamente a superação do subdesenvolvimento. Embora a definição de subdesenvolvimento tenha sido ela mesma sujeita a discussões nos anos posteriores à criação dessas comissões, parecia claro e

${ }^{3}$ http://www.unece.org/oes/history/history.html 
agora evidente que a criação da CEPAL atendia a demandas regionais que não podiam ser negadas pela ONU, à custa de evidenciar descaso político com a região da América Latina.

Outro aspecto relevante e que sobressaía naquela conjuntura de criação das primeiras comissões regionais de cooperação econômica era o de suscitar o comércio internacional. A razão mais visível era procurar suprir insuficiências produtivas nacionais dos países diretamente afetados pela guerra, mas havia uma razão estratégica, de particular interesse dos Estados Unidos, que era ampliar mercados para as empresas americanas. Numa perspectiva histórica, aberta pelo distanciamento que uma análise atual permite, o incremento do comércio suscitou avanço das empresas americanas. $O$ período dos anos 1950 é conhecido na literatura especializada de relações econômica internacionais e economia como um período de internacionalização do capital produtivo (BAMBIRRA, 2012; CANO, 2007; SUZIGAN, 1986).

Cabe observar que no caso dos países da Europa houve certa sobreposição entre as funções da comissão econômica e a precursora da atual OCDE (Organização para a Cooperação e Desenvolvimento Econômico). Em1948, foi criada a Organização para a Cooperação Econômica (OECE) com o objetivo de dar suporte à gestão do Plano Marshall para a reconstrução dos países afetados diretamente pela Guerra. Posteriormente, a sua filiação foi estendida a estados não-europeus, embora com critérios seletivos de ingresso. Em 1961, a Convenção sobre a Organização para a Cooperação e Desenvolvimento Económico reformou a OECE e deu lugar à OCDE. Esta sobreposição de funções confere elementos de suporte à nossa interpretação de circunscrição das funções da ECE em comparação à CEPAL, a primeira muito mais limitada a ações de infraestrutura e estímulo ao comércio.

A OCDE é composta na sua maior parte por países capitalistas ricos, de elevada renda per capita. Dos trinta e cinco países membros atuais, apenas dois deles, México e Chile, são da região de abrangência da CEPAL, mesmo assim, são membros de admissão recente, dos anos 1990 em diante, quando a hegemonia Neoliberal já estava estabelecida internacionalmente. O Quadro 1 mostra a cronologia de formação da organização.

\section{Quadro 1 - Cronologia da composição da OCDE}

\begin{tabular}{|cccc|}
\hline $\begin{array}{c}\text { Membros } \\
\text { fundadores (1948) }\end{array}$ & $\begin{array}{c}\text { Admitidos } \\
\text { nos anos 1950 }\end{array}$ & $\begin{array}{c}\text { Admitidos } \\
\text { em 1961 }\end{array}$ & $\begin{array}{c}\text { Admitidos } \\
\text { posteriormente }\end{array}$ \\
\hline
\end{tabular}




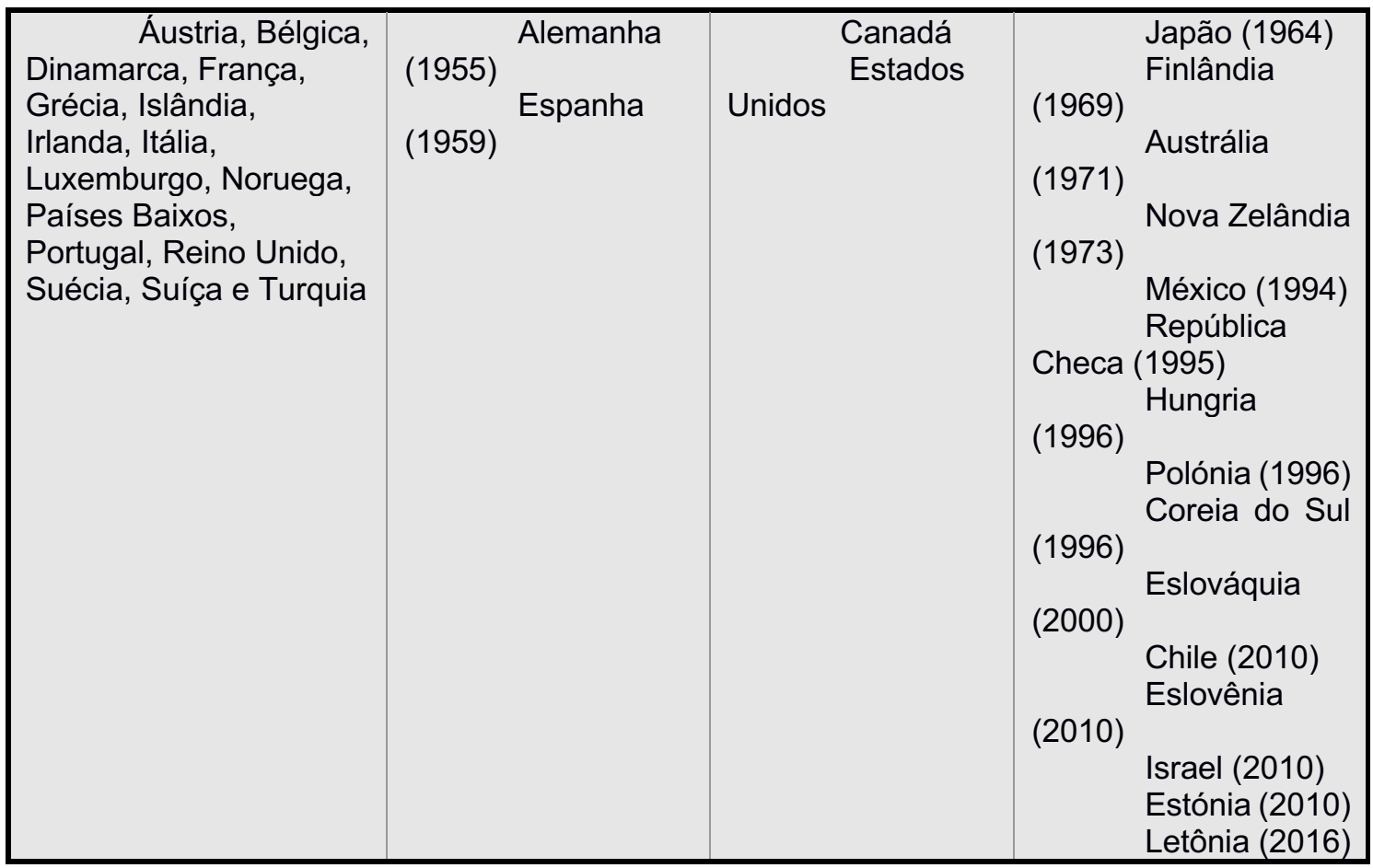

Fonte: OCDE, 2019.

A (OECE) emergiu do Plano Marshall e da Conferência dos Dezesseis (Conferência para a Cooperação Econômica Europeia), que buscava estabelecer uma organização permanente para continuar trabalhando em um programa conjunto de recuperação e, em particular, para supervisionar a distribuição da ajuda. A sede da Organização estava em Paris, França ${ }^{4}$.

A organização foi criada em caráter permanente de cooperação econômica, funcionando de acordo com os seguintes princípios: promover a cooperação entre os países participantes e os seus programas nacionais de produção para a reconstrução da Europa; desenvolver o comércio intra-europeu, reduzindo as tarifas e outros obstáculos à expansão do comércio; estudar a viabilidade de criar uma união aduaneira ou área de livre comércio; estudar a multilateralização dos pagamentos; e alcançar condições para uma melhor utilização do trabalho.

A composição original foi de 16 participantes: Áustria, Bélgica, Dinamarca, França, Grécia, Islândia, Irlanda, Itália, Luxemburgo, Países Baixos, Noruega, Portugal, Suécia, Suíça, Turquia, Reino Unido. A Alemanha Ocidental foi originalmente representada pelas zonas de ocupação americanas e britânicas combinadas e a zona

\footnotetext{
${ }^{4}$ Informações obtidas em http://www.oecd.org/general/organisationforeuropeaneconomicco-operation.htm
} 
de ocupação francesa; a zona anglo-americana do Território Livre de Trieste também participou da OECE até retornar à soberania italiana.

Representantes desses países e territórios participaram do Conselho da Organização. As decisões exigiam unanimidade. O Conselho nomeou um comitê executivo de sete membros, com delegação parcial de poderes entre as reuniões plenárias do Conselho. A estrutura de negócios dos órgãos subordinados do Conselho da OECE consistiu em cerca de quinze comitês técnicos verticais e cinco comissões técnicas horizontais responsáveis pelo tratamento de áreas específicas: alimentação e agricultura, carvão, eletricidade, petróleo, ferro e aço, matérias-primas, máquinas, metais não ferrosos, produtos químicos, madeira, celulose e papel, têxteis, transportes marítimos e terrestres, programas, balança de pagamentos, comércio, pagamentos intraeuropeus e mão-de-obra.

O primeiro objetivo da OECE em 1948/1949 foi preparar o Programa Europeu de Recuperação que justificou o esforço americano. Houve dificuldades com alguns países beneficiários que se revelaram incapazes de chegar a acordo sobre a harmonização prévia dos seus programas de longo prazo.

O aspecto a realçar, para não alongar neste apêndice ao argumento principal, é que a natureza da ECE é única, embora pelas suas características de abranger os principais países e economias do mundo ela tenha ficado limitada em suas funções, pela impossibilidade de acordo numa região que se constituiu como palco central da "Guerra Fria". Por outro lado, ela foi única também por abranger um conjunto de países que compunham os dois grandes blocos políticos em conflito, sob a liderança dos EUA e URSS.

No caso da ESCAP, as limitações foram muito mais pela heterogeneidade da composição dos países e economias. Isto não significa dizer que os conflitos geopolíticos não se apresentassem de forma relevante. Havia uma tensão permanente entre China e Japão, mitigada pela presença dos EUA. A revolução chinesa estava em curso, completando-se em 1949. Daí em diante a China fechou-se ao mundo.

As duas outras comissões regionais, a ECA e ESCWA, seguiram orientação semelhante suscitada por circunstâncias históricas particulares. A ECA foi criada em 1958 num momento em que as tensões na Ásia se agudizavam. Ademais, a ECA foi criada em meio ao processo de descolonização do continente africano, portanto, ainda num momento em que a configuração atual de 54 países estava incipiente. Da mesma 
forma, a ESCWA foi criada em um momento de fortes tensões regionais, particularmente o conflito entre árabes e judeus, explicitados fortemente em duas guerras (1967 e 1973), sendo uma delas exatamente no ano de criação da ESCWA.

\section{As resoluções e missões específicas de cada uma das comissões regionais}

Em decorrência das circunstâncias já descritas, as resoluções de criação das três primeiras comissões - ECA, ESCAP e CEPAL - são muito parecidas, exceto por um parágrafo complementar na resolução de criação da CEPAL:

A Comissão centrar-se-á, em particular, no estudo e na constatação de soluções para os problemas de incompatibilidade econômica global na América Latina e para os problemas relacionados com a economia mundial, a fim de obter a cooperação de países latino-americanos no esforço comum para alcançar a recuperação e a estabilidade econômica em todo o mundo 5 .

Ainda quanto à diferenciação da natureza das comissões econômicas, havia (e ainda há) grande disparidade política, social e de desenvolvimento econômico entre os países membros de cada comissão. A disparidade de dimensão das populações era enorme, conforme pode ser observado pelo quadro abaixo, que dá uma referência aproximativa da região de abrangência das comissões econômicas regionais.

\section{Quadro 2 - População por regiões selecionadas - número de habitantes}

\begin{tabular}{|c|r|r|r|}
\hline Regiões & \multicolumn{1}{|c|}{1960} & \multicolumn{1}{c|}{1970} & \multicolumn{1}{c|}{1980} \\
\hline $\begin{array}{c}\text { Leste da Ásia } \\
\text { \& Pacífico }\end{array}$ & 1.042 .016 .96 & 1.288 .580 .6 & 1.557 .506 .468 \\
\hline $\begin{array}{c}\text { Europa \& } \\
\text { Ásia Central }\end{array}$ & 667.246 .384 & 737.948 .178 & 793.937 .090 \\
\hline $\begin{array}{c}\text { América } \\
\text { Latina e Caribe }\end{array}$ & 220.434 .162 & 287.360 .913 & 363.540 .795 \\
\hline Mundo Árabe & 92.490 .932 & 122.398 .374 & 165.689 .490 \\
\hline $\begin{array}{c}\text { África e } \\
\text { Oriente Médio }\end{array}$ & 351.410 .562 & 454.178 .446 & 600.122 .943 \\
\hline
\end{tabular}

Fonte: WDI, Banco Mundial. Última atualização em 19 / 01 / 2018

O mesmo se pode afirmar a respeito das dimensões geográficas:

${ }^{5}$ ECOSOC (1948) Item 2 da Resolução de 25 de fevereiro e 5 de março de 1948 (documento E / 712 / Rev. 1) de criação da CEPAL. Tradução livre do autor. 
NIEMEYER ALMEIDA FILHO

\begin{tabular}{|c|c|c|}
\hline \multicolumn{2}{|c|}{ Quadro 3 - Área - km² } \\
\hline Regiões & 1970 & 1980 \\
\hline $\begin{array}{l}\text { Leste da Ásia \& } \\
\text { Pacífico }\end{array}$ & 24.402 .270 & 24.401 .760 \\
\hline $\begin{array}{l}\text { Europa \& Ásia } \\
\text { Central }\end{array}$ & 27.358 .427 & 27.358 .057 \\
\hline $\begin{array}{l}\text { América Latina e } \\
\text { Caribe }\end{array}$ & 20.071 .304 & 20.071 .224 \\
\hline Mundo Árabe & 13.624 .031 & 13.623 .991 \\
\hline $\begin{array}{c}\text { África e Oriente } \\
\text { Médio }\end{array}$ & 36.070 .131 & 36.069 .291 \\
\hline
\end{tabular}

Fonte: WDI, Banco Mundial. Última atualização em 19 / 01 / 2018

Ainda que as disparidades de população e território sejam comuns a todas as comissões, é possível afirmar que as diferenças entre os países membros da CEPAL eram relativamente menores, pois esses países foram formados, na sua maioria, no mesmo período histórico (início do Século XIX).

Em Gonçalves (2011), há recuperação das circunstâncias de criação da CEPAL e do papel da diplomacia brasileira para que a comissão se tornasse permanente, num detalhamento do que afirmamos na seção anterior:

A história da CEPAL teve seu início em 14 de julho de 1947, quando o Embaixador do Chile junto às Nações Unidas, Hernán Santa Cruz, solicitou oficialmente ao Secretário Geral da ONU que incluísse, no próximo período de sessões do Conselho Econômico e Social (ECOSOC), um projeto de resolução com a proposta de criação de uma Comissão Econômica para a América Latina. Anos mais tarde, Santa Cruz declarou ter agido sem o consentimento de seu governo, que só enviou mensagem de apoio ao Embaixador alguns dias depois. Justificou sua atitude afirmando que "por la decision que tomé al iniciar mi misión en las Naciones Unidas de ocuparme principalmente en 
la tarea de mejorar las condiciones de América Latina" (GONÇALVES, 2011:23).

A iniciativa foi progressivamente acolhida por outros governos da região:

Todos os países latino-americanos, inclusive o Brasil (representado na ONU pelo Embaixador João Carlos Muniz), endossaram a proposta chilena. O que atraiu o interesse do Brasil foi o enfoque dado por Santa Cruz de fomentar o processo de industrialização na América Latina e de levar adiante o processo de renovação do maquinário industrial desses países, gasto até o esgotamento quase completo ao longo dos anos de guerra (idem, ibidem).

A proposta de criação da CEPAL foi a princípio contestada por parte dos países já industrializados, tanto os da Europa quanto os da América do Norte, embora a posição decisiva neste período fosse a americana. As quatro contestações foram: a) a do Canadá, que considerava um erro regionalizar o trabalho da ONU na esfera econômica; b) a Grã-Bretanha que considerava as circunstâncias da América Latina distintas das da Europa e Ásia/Extremo Oriente, enfatizando que as duas outras comissões tinham caráter temporário; c) os EUA, que viam sobreposição entre o recentemente criado Conselho Interamericano Econômico e Social (CIES) e a comissão proposta; e d) o argumento de que a América Latina não havia sido palco da guerra. (GONÇALVES, 2011, p. 24)

Foi criado um comitê para estudar a viabilidade da criação da comissão formado por nove países, incluindo os quatro países da região que ocupavam assentos no ECOSOC. Após negociações, a comissão foi criada, como as demais, em caráter emergencial, a ser avaliado em três anos. Foi este período inicial, engendrado pelas circunstâncias históricas, que definiu a natureza da CEPAL e deu a diretriz que veio a ser a sua marca distintiva, denominada na literatura especializada como a Escola Cepalina, considerada heterodoxa no contexto do debate da época sobre desenvolvimento econômico (ou melhor, do subdesenvolvimento econômico).

As condições de criação da ECA foram outras. Houve demanda regional, porém em outros termos se comparada à CEPAL. A diferença decisiva é que os países da 
região da África, na sua maior parte, enquadravam-se na condição que os teóricos seminais do desenvolvimento chamaram de economia tradicional, estagnada, ou em situações de independências recentes (HUNT, 1989; ROSTOW, 1961).

\section{Quadro 4 - Datas de independência e tipo de colonização dos países} africanos

\begin{tabular}{|c|c|c|c|}
\hline \multicolumn{2}{|c|}{ Colonização francesa } & \multicolumn{2}{|c|}{ Colonização britânica } \\
\hline $\begin{array}{l}\text { Países/eco } \\
\text { nomias nacionais }\end{array}$ & $\begin{array}{r}\text { Datas de } \\
\text { independência }\end{array}$ & $\begin{array}{l}\text { Países/economi } \\
\text { as nacionais }\end{array}$ & $\begin{array}{l}\text { Datas de } \\
\text { independência }\end{array}$ \\
\hline Argélia & $\begin{array}{l}9 \text { de março } \\
\text { de } 1962\end{array}$ & África do Sul & 31 de maio de 1961 \\
\hline Benim & $\begin{array}{l}1 \text { de agosto } \\
\text { de } 1960\end{array}$ & Botswana & $\begin{array}{l}30 \text { de setembro de } \\
1966\end{array}$ \\
\hline $\begin{array}{l}\text { Burkina } \\
\text { Faso }\end{array}$ & $\begin{array}{l}5 \text { de agosto } \\
\text { de } 1960\end{array}$ & Egito & $\begin{array}{l}18 \text { de junho de } \\
1953 \text { (1922) }\end{array}$ \\
\hline Burundi & $\begin{array}{l}1 \text { de julho de } \\
1962\end{array}$ & Eritreia & $\begin{array}{l}24 \text { de março de } \\
1993\end{array}$ \\
\hline Camarões & $\begin{array}{l}1 \text { de janeiro } \\
\text { de } 1960\end{array}$ & Gâmbia & $\begin{array}{l}18 \text { de fevereiro de } \\
1965\end{array}$ \\
\hline Chade & $\begin{array}{r}11 \mathrm{de} \\
\text { agosto de } 1960\end{array}$ & Gana & 6 de março de 1957 \\
\hline Comores & $\begin{array}{l}6 \text { de julho de } \\
1975\end{array}$ & Lesoto & $\begin{array}{l}4 \text { de outubro de } \\
1966\end{array}$ \\
\hline Congo & $\begin{array}{l}30 \text { de junho } \\
\text { de } 1960\end{array}$ & Malaui & 6 de julho de 1964 \\
\hline $\begin{array}{l}\text { Costa do } \\
\text { Marfim }\end{array}$ & $\begin{array}{l}7 \text { de agosto } \\
\text { de } 1960\end{array}$ & Maurícia & $\begin{array}{l}12 \text { de março de } \\
1968\end{array}$ \\
\hline Djibuti & $\begin{array}{l}27 \text { de junho } \\
\text { de } 1977\end{array}$ & Namíbia & $\begin{array}{l}21 \text { de março de } \\
1990\end{array}$ \\
\hline Gabão & $\begin{array}{r}17 \mathrm{de} \\
\text { agosto de } 1960\end{array}$ & Nigéria & $\begin{array}{l}1 \text { de outubro de } \\
1960\end{array}$ \\
\hline Guiné & $\begin{array}{l}2 \text { de outubro } \\
\text { de } 1958\end{array}$ & Quênia & $\begin{array}{l}12 \text { de dezembro de } \\
1963\end{array}$ \\
\hline $\begin{array}{l}\text { Madagásca } \\
\mathbf{r}\end{array}$ & $\begin{array}{l}26 \text { de junho } \\
\text { de } 1960\end{array}$ & Serra Leoa & 27 de abril de 1961 \\
\hline Mali & $\begin{array}{c}22 \text { de } \\
\text { setembro de } 1960\end{array}$ & Seychelles & $\begin{array}{l}29 \text { de junho de } \\
1976\end{array}$ \\
\hline Marrocos & $\begin{array}{l}2 \text { de março } \\
\text { de } 1956\end{array}$ & Somália & 1 de julho de 1960 \\
\hline Mauritânia & $\begin{array}{c}28 \text { de } \\
\text { novembro de } 1960\end{array}$ & Suazilândia & $\begin{array}{l}6 \text { de setembro de } \\
1968\end{array}$ \\
\hline Níger & $\begin{array}{l}3 \text { de agosto } \\
\text { de } 1960\end{array}$ & Sudão & $\begin{array}{l}1 \text { de janeiro de } \\
1956\end{array}$ \\
\hline
\end{tabular}




\begin{tabular}{|c|c|c|c|}
\hline $\begin{array}{l}\text { República } \\
\text { Centro-Africana }\end{array}$ & $\begin{array}{r}13 \mathrm{de} \\
\text { agosto de } 1960\end{array}$ & Sudão do Sul & 9 de julho de 2011 \\
\hline Senegal & $\begin{array}{l}4 \text { de abril de } \\
1960\end{array}$ & Tanzânia & $\begin{array}{l}9 \text { de dezembro de } \\
1961\end{array}$ \\
\hline Togo & $\begin{array}{l}27 \text { de abril } \\
\text { de } 1960\end{array}$ & Uganda & $\begin{array}{l}9 \text { de outubro de } \\
1962\end{array}$ \\
\hline \multirow[t]{2}{*}{ Tunísia } & $\begin{array}{l}20 \text { de março } \\
\text { de } 1956\end{array}$ & Zâmbia & $\begin{array}{l}24 \text { de outubro de } \\
1964\end{array}$ \\
\hline & & Zimbábue & 18 de abril de 1980 \\
\hline \multicolumn{2}{|c|}{ Outras colonizações } & \multicolumn{2}{|c|}{ Colonização portuguesa } \\
\hline $\begin{array}{c}\text { Guiné } \\
\text { Equatorial } \\
\text { (espanhola) }\end{array}$ & $\begin{array}{c}12 \mathrm{de} \\
\text { outubro de } 1968 .\end{array}$ & Angola & $\begin{array}{l}11 \text { de novembro de } \\
1975\end{array}$ \\
\hline $\begin{array}{l}\text { Rep. Demo. } \\
\text { do Congo (belga) }\end{array}$ & $\begin{array}{l}30 \text { de junho } \\
\text { de } 1960\end{array}$ & Cabo Verde & 5 de julho de 1975 \\
\hline $\begin{array}{l}\text { Ruanda } \\
\text { (belga) }\end{array}$ & $\begin{array}{l}1 \text { de julho de } \\
1962\end{array}$ & Guiné-Bissau & $\begin{array}{l}24 \text { de setembro de } \\
1973\end{array}$ \\
\hline $\begin{array}{l}\text { Libéria } \\
\text { (americana) }\end{array}$ & $\begin{array}{l}26 \text { de julho } \\
\text { de } 1847\end{array}$ & Moçambique & $\begin{array}{l}25 \text { de junho de } \\
1975\end{array}$ \\
\hline $\begin{array}{l}\text { Etiópia } \\
\text { (italiana) }\end{array}$ & $\begin{array}{r}31 \mathrm{de} \\
\text { janeiro de } 1941\end{array}$ & $\begin{array}{l}\text { São Tomé e } \\
\text { Príncipe }\end{array}$ & 12 de julho de 1975 \\
\hline $\begin{array}{l}\text { Líbia } \\
\text { (italiana) }\end{array}$ & $\begin{array}{c}24 \\
\text { dezembro } 1951\end{array}$ & & \\
\hline
\end{tabular}

Fonte: Wikipédia.

Ademais, o contexto histórico, político, recomendava ações de consolidação dos interesses civilizatórios tanto dos EUA, como país hegemônico, quanto das antigas metrópoles, que pretendiam resguardar seus interesses econômicos numa organização formal de multilateralismo. O quadro 4 mostra os marcos nacionais de independência do continente Africano. Em 1960, logo em seguida à criação da ECA, houve 17 processos de independência, sendo 14 deles de colônias francesas.

No final da II Guerra Mundial, em África, apenas Etiópia, Libéria e Egito eram independentes e quando os anos 1950 chegaram ao fim ainda só se Ihes tinham juntado Líbia, Marrocos, Sudão, Tunísia, Gana e Guiné-Conacri. Mas a vaga de independências de 1960, principalmente de colónias francesas, mostrou que a tendência era irreversível. Logo a 1 de janeiro tornou-se soberanos os Camarões franceses, que no ano seguinte se unificariam com os britânicos. Em abril foi a vez do Togo. E em junho aconteceu o mesmo com a 
Federação do Mali e depois com Madagáscar. Em três semanas de agosto surgiram nove países francófonos, incluindo o Senegal, que só convivera dois meses com o Mali após o corte com a metrópole, que ainda vivia a ressaca da derrota na Indochina e estava a braços com a insurreição argelina. Já em novembro a Mauritânia separava-se do colonizador, pondo fim ao sonho alimentado por De Gaulle, referendado em 1958, de uma "comunidade": os estados autónomos tornavam-se soberanos, ainda que em muitos casos a influência de Paris se prolongasse por décadas. Também em 1960 o Reino Unido abriu mão da Nigéria e do território que, com uma colónia italiana, deu origem à Somália. A Bélgica viu-se forçada a deixar o Congo. Num ápice, o mapa de África mudava (ROCHA, 2010, https://www.publico.pt/2010/02/13/mundo/noticia/africa-o-ano-emque-comecou-um-futuro-ainda-por-cumprir-1422629).

As informações oficiais da ECA apontam para um processo de criação da comissão inspirado nos propósitos de ampliar o comércio com a região, mantendo a influência das antigas metrópoles, porém num contexto aparente de multilateralismo.

Ao longo da sua existência, a ECA tem tentado definir o seu papel no desenvolvimento e tem experimentado dificuldades. Existem três razões principais para isso. Em primeiro lugar, os problemas originados de seu status como um braço das Nações Unidas. Os termos de referência indicam várias possibilidades do que ela pode fazer como a coleta de dados e a análise dos resultados, pesquisas, publicação de relatórios anuais e boletins e a realização de seminários e workshops. Mas não houve ordenação de prioridades ou ênfase específica em aspectos considerados mais vitais para os membros. Os seus programas são amplamente baseados, mesmo quando alguns Estados como os PMD (países menos desenvolvidos) têm necessidades peculiares que requerem uma atenção especial. Mas a ECA não está sozinha, pois todas as comissões regionais têm estruturas e âmbito de atividades semelhantes. Em segundo lugar, o grau de crise econômica, a escala em que ocorreu e a sua natureza persistente, salienta ainda que a ECA terá dificuldades se quiser desempenhar um papel positivo e de liderança na sua resolução ou no 
início da mudança de desenvolvimento que a África precisa tão intensamente. A Comissão desenvolveu uma burocracia complexa que dificulta a adaptação às alterações das condições econômicas dos Estados. Por exemplo, os Estados têm dado a autossuficiência na agricultura prioridade máxima nos seus esforços para melhorar o nível de vida das suas populações, mas os programas da ECA não refletem esta ênfase. Por último, embora o objetivo fundamental de todas as comissões econômicas regionais fosse ajudar a elevar o nível de atividade econômica nas respectivas regiões e a manter e reforçar as relações econômicas dos países de cada região, tanto entre e com outros países do mundo, nenhum foi equipado com os órgãos necessários para permitir que eles implementem atividades orientadas para o projeto. Por projeto, queremos dizer uma atividade com objetivos e objetivos claros, que também tem valor agregado líquido, ou seja, que deve contribuir para o rendimento nacional dos respectivos Estados. Também deve ser possível fazer uma análise custo-benefício e outras formas de avaliação e devemos ser capazes de avaliar se ela contribui para a melhoria das condições de vida física das pessoas. Ao solicitarem projetos em vez dos programas gerais oferecidos, os Estados-Membros estavam a fazer exigências que questionavam a finalidade da Comissão (EKPENYONG, 1989, p.2324).

Em Ekpenyong (1989) há elementos adicionais. Ele descreve fatos históricos, sobretudo mobilizações diplomáticas, que atestam que houve demanda de criação de uma comissão regional para a África ainda em 1947. Segundo ele, o embrião institucional da criação das comissões para Europa (ECE) e Ásia e Extremo Oriente (ESCAP) foi a comissão para reconstrução da Europa, criada em 1946, dividida em seguida em duas subcomissões, sendo uma para a Europa e norte da África e Etiópia, outra para a Ásia e Extremo Oriente. A missão era levantar as informações das condições regionais de modo a subsidiar as ações da ONU para reconstrução das regiões afetadas diretamente pela guerra. Dessas subcomissões nasceram as duas primeiras comissões regionais. Por razões não explicitadas oficialmente pelo ECOSOC, o Norte da África foi esquecido. 
Ao examinar os relatórios dos dois grupos e ao responder à resolução 46 (1) da Assembleia Geral de 11 de dezembro de 1946, o ECOSOC estabeleceu a Comissão Econômica para a Europa (ECE) e a Comissão Econômica para a Ásia e o Extremo Oriente (ECAFE, agora ESCAP), respectivamente, pela sua resolução 36 (v) e 37 (IV) de 28 de março de 1947. Estas resoluções também estipularam os seus termos de referência, que são bastante semelhantes para todas as comissões e serão delineados mais tarde. Em 11 de agosto de 1947, o Conselho, por outra de suas resoluções-70 (v)-estabeleceu a terceira comissão, a Comissão Econômica para a América Latina (ECLA, agora CEPAL); e, pela sua resolução 72 (v), solicitou à Comissão Econômica e do Emprego que examinasse e relatasse ao Conselho as questões gerais envolvidas na criação das comissões como meio de promoção dos objetivos das Nações Unidas. O Conselho registou que a Subcomissão temporária sobre a construção econômica das zonas devastadas não tinha comunicado sobre os problemas de reconstrução do norte de África e da Etiópia. Depois de tomar nota disto, a Subcomissão temporária encerrou as suas atividades (idem, p. 26).

Foi somente em 1958 que a ECA foi criada, por deliberação da Assembleia Geral da ONU. Antes disto, ainda em 1957, a criação da ECA foi sugerida pela representação de Gana. A sugestão foi acompanhada pela representação de outros seis países. $\mathrm{O}$ esboço da resolução final contou com 29 representações de apoio (ASFOUR,1960).

Após os primeiros dois anos, que parecem ter sido de instalação da comissão, as ações iniciais da ECA foram inspiradas em referências teóricas e ideológicas da CEPAL. Conforme Ewing (1964), os debates e proposições das Teorias de Desenvolvimento foram importantes elementos referenciais para a criação da ECA, sobretudo a ideia de que o processo de industrialização da região seria essencial, num contexto de cooperação internacional regional. Ele faz referência direta às contribuições de Prebisch e Gunnar Myrdal como tendo sido fundamentais na definição inicial das proposições e ideologia da comissão. Esta avaliação coincide com a circunstância de criação da UNCTAD em 1964, liderada por Raúl Prebisch. A UNCTAD foi criada para promover integração de países em desenvolvimento na economia mundial num período histórico 
em que o GATT promovia ações de promoção do comércio internacional. A ideologia do órgão foi influenciada pela experiência de Prebisch na direção da CEPAL no período de 1950 a 1963.

A criação da ESCWA tem origem distinta, embora tenha sido proposta por um membro da Assembleia Geral. Considerando o contexto do início dos anos 1970, em particular as disputas relacionadas às reservas de petróleo presentes no Oriente Médio, a criação da ESCWA seguiu a estratégia da ONU de construir pontes de cooperação regional em regiões de conflito, a partir do seu ideário de base. $\mathrm{O}$ ano de criação da comissão coincide com um segundo grande conflito bélico na região, a guerra do Yom Kippur, em 1973, de modo que a criação da comissão se origina numa preocupação de instituir um órgão cuja missão fosse atenuante das tensões regionais, centrada sobretudo em cooperação econômica a partir do ideário da ONU. Antes disto, houve a guerra de 1967 de Seis Dias, na qual Israel ocupou regiões para além de seu território original na Palestina. Esta intenção aparentemente não se concretizou a contento, pois há indicações de mudança de rumos nas diretrizes da comissão a partir dos anos 1990, a exemplo das demais comissões.

O contexto de conflito explica também a sobreposição da região de abrangência da ESCWA com a ECA. Mauritânia, Marrocos, Egito, Tunísia, Líbia e Sudão são também membros da ECA. Além deles, a comissão tem como membros geográficos 6 Jordânia, Bahrain, Líbano, Síria, Iraque, Kuwait, Arábia Saudita, Catar, lêmen, Emirados Árabes, Omã e o Estado da Palestina.

No que diz respeito às resoluções de criação, ECA e ESCWA apresentam, como no caso da CEPAL, diferenças em relação a ECE e ESCAP. Há uma passagem idêntica nas resoluções de criação dessas duas comissões na parte que trata das competências e que se diferencia das resoluções das três primeiras comissões econômicas:

a) iniciar e participar de medidas destinadas a facilitar a ação concertada para o desenvolvimento econômico de África [e da Ásia e

\footnotetext{
${ }^{6}$ As comissões têm membros que estão fora da área geográfica de abrangência. Em todas as cinco resoluções de criação há um parágrafo dizendo que qualquer país da ONU pode se candidatar a membro de quaisquer das cinco comissões. Na literatura que trata da CEPAL é comum a referência a esses países como sendo aqueles que têm algum tipo de interesse na região. Estamos chamando de membros geográficos aqueles países que estão na região de abrangência das comissões.
} 
Pacífico], incluindo os seus aspetos sociais, com vista a elevar o nível de atividade económica e os níveis de vida na África [e da Ásia e Pacífico], e para manter e reforçar as relações econômicas dos países e territórios da África [e da Ásia e Pacífico], entre si e com outros países do mundo (ECOSOC, 1958, Resolução 671 (XXV), criação de uma Comissão Econômica para África; ECOSOC, 1973, Resolução 1818 (LV), Criação de uma Comissão Econômica para a Ásia Ocidental).

A diferença mais importante em relação à CEPAL está, como já o dissemos, nas características das regiões geográficas de cobertura dessas comissões, que são incipientes em termos de desenvolvimento capitalista. A discussão dessas características foge aos propósitos deste artigo. Não obstante, parece-nos lícito afirmar que essa passagem dos textos das duas resoluções denota uma preocupação da ONU em promover ações sintonizadas com a ideia de constituir referências civilizatórias a partir do que se considerava ser essencial e indispensável: o desenvolvimento econômico capitalista nacional e o comércio internacional.

\section{A especificidade da CEPAL}

A região original de cobertura geográfica da missão da CEPAL era a América Latina. Posteriormente, em 1984, a Comissão incorporou ao seu nome e missão a região do Caribe. A região continental de abrangência da CEPAL apresenta características econômicas semelhantes, ainda que seja perceptível a diferença de tamanho dos países e economias nacionais (Quadro 5). O contexto histórico de desenvolvimento dos países e economias nacionais a partir do século XIX estão descritos em Furtado (1959; 1969) e Thorp (1998). O passado colonial, os processos de independência, a transição ao capitalismo e a especialização produtiva são traços comuns aos países da região.

Quadro 5 - América Latina - População, Território e PIB per capita (2006)

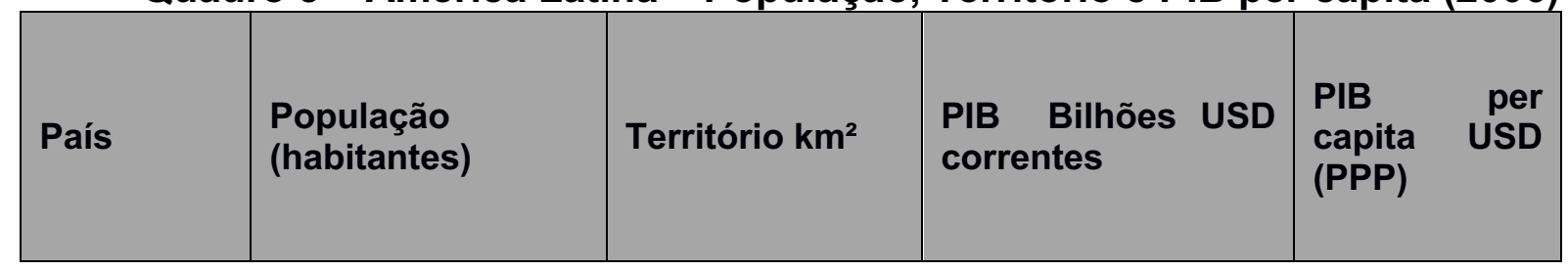




\begin{tabular}{|l|c|c|c|c|}
\hline Argentina & $40,403,943$ & $2,766,889$ & 212.595 & 16,080 \\
\hline Belize & 314,275 & 22,966 & 2,307 & 7,800 \\
\hline Bolívia & $9,627,269$ & $1,098,581$ & 11.221 & 2,931 \\
\hline Brasil & $188,181,069$ & $8,514,876$ & $1,067.706$ & 10,073 \\
\hline Chile & $15,116,435$ & 756,950 & 145.845 & 12,811 \\
\hline Colômbia & $44,379,598$ & $1,141,748$ & 135.883 & 8,260 \\
\hline Costa Rica & $4,327,000$ & 51,100 & 21.466 & 11,862 \\
\hline Cuba & $11,382,820$ & 110,861 & 40.000 & 4,100 \\
\hline El Salvador & $6,881,000$ & 21,041 & 18.654 & 5,600 \\
\hline Equador & $13,363,593$ & 272,045 & 41.402 & 4,835 \\
\hline Guatemala & $14,655,189$ & 108,890 & 30.299 & 4,335 \\
\hline Haiti & $7,500,000$ & 27,750 & 4.473 & 1,840 \\
\hline Honduras & $7,205,000$ & 112,492 & 9.072 & 3,300 \\
\hline México & $106,202,903$ & $1,958,201$ & 840.012 & 11,369 \\
\hline Nicarágua & $5,487,000$ & 130,000 & 5.301 & 3,100 \\
\hline Panamá & $3,232,000$ & 75,517 & 17.103 & 8,593 \\
\hline Paraguai & $5,734,139$ & 406,752 & 9.527 & 5,339 \\
\hline Peru & $28,675,628$ & $1,285,215$ & 107.000 & 7,856 \\
\hline $\begin{array}{l}\text { República } \\
\text { Dominicana }\end{array}$ & $8,900,000$ & 48,734 & 31.600 & 9,377 \\
\hline Uruguai & $3,415,920$ & 176,215 & 19.127 & 11,969 \\
\hline Venezuela & $27,730,469$ & 916,445 & 181.608 & 7,480 \\
\hline
\end{tabular}

Fonte: WDI, Banco Mundial.

Ademais dessa referência comum aos países da região, o que conferiu natureza distinta à CEPAL foi a forma e resultado dos seus primeiros anos de funcionamento. A criação como comissão econômica regional emergencial por um período de três anos exigiu um documento de diagnóstico que pudesse justificar, assim como as outras duas comissões, o status de comissão permanente. Esse diagnóstico e o relatório final coordenado por Raúl Prebisch - Estudo Econômico da América Latina (1949) - deu base ao que poderia ser chamado de consenso industrializante dos anos 1940/1950 na região. A sustentação política decorrente da convergência de posições de governos permitiu que a CEPAL, na sua origem, cumprisse, ademais de se constituir como uma Escola de Pensamento, a função de um think tank e formulasse recomendações de políticas a seus países membros, de 
uma forma bem diferente da ECE e ESCAP, e mesmo da ECA e ESCWA, criadas posteriormente.

Celso Furtado (1988) descreve todas as circunstâncias de criação da CEPAL vistas a partir da sua experiência de participação direta no corpo técnico da comissão desde o período inicial ainda nos anos 19407. O texto foi elaborado a pedido da Universidade das Nações Unidas. Além das informações já apresentadas na seção anterior, Furtado refere-se à participação de indivíduos, particularmente de Raul Prebisch.

Os críticos da industrialização latino-americana eram, em boa parte, pessoas preocupadas com a perda de mercado para os exportadores tradicionais que desta resultaria. O primeiro Estudo Econômico da América Latina, referente ao estado da economia regional em 1948, procurou combater essa tese, fundando-se na monografia Industrialization and Foreign Trade, preparada pelo secretariado da antiga Sociedade das Nações, e publicada em 1945. (...) Esse primeiro ensaio de tímida defesa de industrialização latino-americana foi amplamente superado pelas ideias contidas no estudo "O desenvolvimento da América Latina e seus principais problemas", preparado por Raúl Prebisch, na qualidade de consultor da CEPAL, e igualmente apresentado na Conferência de Havana (segundo período de sessões), que ocorreu em maio de 1949. Prebisch havia observado, da posição privilegiada que ocupara na direção do Banco Central da Argentina, que o comportamento cíclico da economia capitalista era distinto se observado nos países exportadores de produtos industriais (aos quais ele chamava de cêntricos) e nos exportadores de produtos primários (periféricos). Essa visão do conjunto do sistema capitalista constituiu passo fundamental para os subsequentes avanços na compreensão do fenômeno do subdesenvolvimento, que passou a ser visto como uma conformação estrutural e não como "fase" ou "etapa" do desenvolvimento (FURTADO, 1988, p. 88-89).

${ }^{7}$ Celso Furtado foi parte do corpo técnico da CEPAL de 1948 a 1957 (D'AGUIAR, 2013: síntese biográfica de Celso Furtado na primeira página do livro). 
Sobre a importância de Prebisch, sua biografia escrita por Dosman (2008) mostra as circunstâncias pessoais que o levaram a aceitar a responsabilidade de escrever um relatório retratando as condições econômicas e sociais da América Latina. Ao final dos anos 1940, havia desprezo de europeus e americanos a respeito da capacidade de economistas latino-americanos de produzir um relatório de diagnóstico da região em condições de respaldar a manutenção da CEPAL como um órgão permanente da ONU. Esse relatório deveria ser apresentado (como de fato foi) numa conferência da ONU em Havana ao final do ano de 1949. A equipe de trabalho era pequena. Celso Furtado juntou-se ao grupo no segundo semestre daquele ano, exatamente no período em que o relatório estava sendo concluído. Ao final, o documento apresentado por Prebisch constituiu-se no primeiro estudo amplo sobre a região feito por economistas da região. Neste sentido, a CEPAL já na sua origem cumpre uma função distintiva das outras comissões. A sua precariedade inicial foi elemento de liberdade de pensamento, com enorme influência no debate sobre desenvolvimento na América Latina.

Antes de Havana, Prebisch tinha visto a CEPAL como um ator secundário no jogo Interamericano, e ele foi para Havana como um consultor de curto prazo com uma única ideia: apresentar um relatório que traduzisse os anos que ele tinha gasto elaborando uma nova abordagem para a América Latina e desenvolvimento econômico após o qual o seu contrato expiraria, em 31 de julho. Tendo experimentado Havana, no entanto, ele estava agora convencido de que sua liderança na CEPAL poderia ser transformada em um poderoso instrumento para canalizar o regionalismo que seu relatório tinha provocado. Aparente desvantagem de Santiago de localização poderia ser transformada em vantagem: quanto maior a distância de Washington e da sede da ONU em Nova York, maior a sua defesa contra a sua ortodoxia e pressão para se conformar; A CEPAL poderia prosperar como um centro de pesquisa exclusivamente latinoamericano fora da rigidez da Aliança Atlântica. Desde 1945, economistas latino-americanos qualificados tiveram poucas opções além das organizações internacionais sediadas nos EUA ou na Europa; a CEPAL poderia se tornar um local alternativo e contrapeso intelectual para este sangramento de talentos, oferecendo um centro 
autônomo de ideias onde as abordagens regionais para o desenvolvimento poderiam ser exploradas (DOSMAN, 2008, versão Kindle, posição 5147, tradução livre do autor).

No que diz respeito ao interesse do presente artigo, Furtado (1988: 84-86) destaca o grau de convergência política dos governos dos vinte países da América Latina que compunham o total de 51 países da ONU no ano de 1947 em ampliar o entendimento do que seria o processo de "reconstrução" da economia mundial no Pós Segunda Guerra Mundial. Ele específica a resistência americana à criação da CEPAL atribuindo-a ao interesse daquele governo em manter um controle mais direto sobre o continente americano no que diz respeito às políticas de desenvolvimento econômico. Seria mais fácil aos EUA controlar a estrutura da OEA, dada a natureza da organização, de maior autonomia, e que contava desde o início com uma carta regulatória que exigia apenas maioria simples de posições em diversos temas relevantes, sobretudo aqueles de segurança nacional ${ }^{8}$.

A mesma atmosfera de apreensão alcançou a CEPAL em Santiago e escritório da ONU em Nova York, porque o futuro da CEPAL estava em linha com Prebisch. Quando ele chegou ao escritório em 14 de março de 1949 a nova organização ainda estava parcialmente formada, seu papel e funções permaneciam em dúvida, e quase paralisada com receio no conhecimento de que Washington e alguns outros governos preferiram sua morte precoce. O problema da sobrevivência da CEPAL resultou do seu nascimento impugnado em 15 de fevereiro de 1947. O que aconteceu foi que em 1946 os EUA haviam proposto a criação de duas comissões regionais no Conselho econômico e social das Nações Unidas (ECOSOC), a Comissão Econômica para a Europa (ECE), com um secretariado em Genebra, e a Comissão Económica para a Ásia e o Extremo Oriente (ECAFE) a ser localizada em Bangkok. O objetivo de Washington era

\footnotetext{
8 Organização dos Estados Americanos, fundada em 1948. A Carta da OEA entrou em vigência em 1951. As deliberações da Assembleia Geral da OEA são tomadas por maioria simples dos membros, exceto em algumas situações especiais em que se exige dois terços, como é o caso de decisões orçamentárias. No caso da CEPAL, por exemplo, as decisões são também por maioria simples dos membros presentes na Assembleia Geral, porém as decisões devem estar em consonância com as disposições e deliberações do Comissariado da ONU. Neste sentido, a influência de um determinado país (por exemplo, os EUA) se torna mais difícil.
} 
comprometer a ONU na reconstrução dessas regiões danificadas pela guerra, e a ECE e a ECAFE foram aprovadas por unanimidade pelo ECOSOC. (...) Mesmo antes da sessão fundadora da CEPAL, marcada para 7 a 25 de junho de 1948 em Santiago, os EUA usaram a nona Conferência Interamericana em Bogotá em abril de 1948 para reformular a antiga União Pan-americana como a nova Organização dos Estados Americanos (OEA) e lançar uma desafio, ao aumentar o seu orçamento de $\$ 40000$ para $\$ 500000$ - ou o equivalente ao orçamento total projetado da CEPAL para 1949. Além da oposição oficial, nós, acadêmicos, também criticamos a formação da CEPAL. Simon G. Hanson, editor de uma nova revista, Assuntos Econômicos Interamericanos, lançou seu primeiro ataque antes mesmo do novo órgão regional ter sido estabelecido. "A vida será complicada", David Owen reclamou, "pela existência de duas comissões econômicas paralelas para a América Latina com termos virtualmente idênticos de referência e orçamentos iguais." Ele se perguntou se eles deveriam considerar mudar a sede da CEPAL de Santiago para mais perto de Washington e Nova York; considerando que ia ser difícil recrutar pessoal para um local tão longe de qualquer lugar (DOSMAN, 2008, versão Kindle, posições 4841 e 4847, tradução livre do autor).

O ponto crucial de divergência está muito bem descrito em Reinert (2016), particularmente no capítulo 5 em que o autor desenvolve o argumento de como os países pobres ficaram ainda mais pobres no contexto da Segunda Guerra Mundial. Em síntese, o argumento é que os EUA e os países europeus desenvolvidos e industrializados passaram a bloquear o processo de industrialização da periferia, utilizando a tese das "vantagens comparativas" da especialização produtiva. Esta tese está problematizada na metáfora do título e no conteúdo do livro de Ha-Joon Chang, Chutando a Escada (2004). A tese sustenta que as economias nacionais deveriam se especializar naqueles produtos em que tivessem vantagens comparativas no comércio internacional. Reinert mostra como a tese está em contradição com o processo histórico de desenvolvimento daquelas economias consideradas de industrialização atrasada em relação à Inglaterra, particularmente os EUA, que se 
utilizaram largamente da ação protetora do Estado em favor do processo de industrialização.

O Estudo da América Latina da CEPAL mostrava claramente a desvantagem em se manter os marcos da divisão internacional do trabalho que reservava aos países da América Latina a função de supridores de matérias-primas às economias industrializadas da Europa e dos EUA.

Este texto [do Manifesto], a rigor, não contemplava uma crítica da teoria clássica (ou neoclássica) do comércio internacional, sendo em realidade uma denúncia do sistema de divisão internacional do trabalho prevalecente, o qual vinha provocando, no longo prazo, concentração da renda em benefício dos centros exportadores de produtos manufaturados. A tese da degradação dos termos de intercâmbio dos países exportadores de produtos primários, adotada por Prebisch, tinha como fundamento o estudo sobre a matéria, preparado em 1948 por Hans Singer para o Departamento Econômico e Social das Nações Unidas. Prebisch procurou explicar o comportamento dos termos de intercâmbio, comprovado por Singer, situando-o no ciclo da economia capitalista: na fase de expansão, os salários monetários sobem, nos países cêntricos, mais do que a produtividade - processo não totalmente reversível na fase de baixa do ciclo, em razão da resistência que oferecem as organizações operárias. Inexistindo tal resistência na periferia, o comportamento cíclico engendrava transferência de renda em seu desfavor. Subsequentemente, Prebisch refinou este ponto de sua análise, dando ênfase às diferenças nas elasticidades-renda das demandas de produtos primários e manufaturados e ao peso crescente da oferta de substitutivos sintéticos às matérias-primas naturais (FURTADO,1988, p. 90).

Por outro lado, ainda com referência a Dosman (2008), especialmente no capítulo que antecede a passagem de Prebisch na CEPAL e que vimos de apresentar (capítulo 10), há apontamentos dos problemas políticos regionais de confrontos de governos. No período do pós-guerra que estamos tratando, anos 1940 e 1950, houve tensões entre os governos da Argentina e do Brasil. Na Argentina, Juan Domingo Perón ocupou o governo em dois mandatos (1946/1952/1955). Ao longo do seu 
primeiro mandato, exatamente no período de criação da CEPAL, o governo brasileiro foi ocupado por Eurico Gaspar Dutra (1946 a 1950), de base desenvolvimentista. Posteriormente, o governo brasileiro foi ocupado por Getúlio Vargas (1950 a 1954). Embora de objetivos semelhantes, os dois países disputavam a hegemonia política regional. Um elemento importante de diferenciação dos dois governos foi a posição de independência de Perón em relação ao conflito da Guerra Fria. Além desses confrontos que se apresentavam nos espaços diplomáticos da ONU, Dosman descreve outros problemas da geopolítica regional, de modo que havia dificuldades de legitimação de uma ação multilateral na região.

Portanto, o que explica o sucesso da CEPAL nos seus primeiros quinze anos, ao menos, foi a possibilidade e competência de seu corpo técnico em assumir funções de liderança intelectual, a partir de estudos técnicos e da preparação de quadros para o desenvolvimento, e que estavam em consonância com o processo histórico de transformação e desenvolvimento da região. As comissões são, todas elas, elos de relações entre governos, que enfrentavam condições adversas que exigiam, assim como o foram as condições do New Deal nos EUA, ação direta do Estado.

Outro elemento relevante, é que esse corpo técnico propunha planos de desenvolvimento capitalista, num contexto de Guerra Fria e de gestação da Revolução Cubana (CAMARINHA et. al., 2018). As condições históricas de desenvolvimento econômico das economias nacionais da região eram muito receptivas a proposições de desenvolvimento que pudessem acelerar o progresso social regional. É como se as proposições da CEPAL viessem para dar suporte ao pensamento político que vinha se consolidando em nível de diversos governos.

A nossa proposição é que este período inicial foi suficientemente importante para influenciar o futuro da comissão, mesmo em sucessivas conjunturas nas quais houve intervenção política e administrativa do Comissariado da ONU. Dessas conjunturas, merecem destaque duas, sendo uma aquela que marca a abertura dos anos 1990, de esgotamento das experiências socialistas na Europa; outra, a de implementação dos ODS em 2015. Nessas duas conjunturas, as diretrizes internas ao sistema ONU foram de forte intervenção, formuladas a partir da hegemonia do Neoliberalismo. Nas duas situações, a CEPAL foi obrigada a absorver elementos importantes de mudança em suas recomendações, porém sem que isto afetasse 
aquilo que a literatura especializada chama de método histórico-estrutural (RODRIGUEZ, 2009; BIELSCOWSKY, 2000).

\section{Conclusões}

O objetivo mais amplo deste artigo foi o de estimular o interesse e o estudo das comissões econômicas regionais da ONU. A literatura de Relações Internacionais parece ter relegado este tema por considerá-lo secundário no contexto das organizações internacionais que compõem a institucionalidade das Nações Unidas. Isto está claro no trabalho de Murphy (2014), no qual ele investiga as organizações internacionais desde 1850. O destaque é para as agências internacionais, multilaterais, já que elas têm um grau de autonomia superior ao das comissões regionais. A tese central do autor é que a regulação desenvolvida no âmbito supranacional foi essencial para a expansão do capitalismo no Pós Segunda Guerra Mundial.

A este respeito, o que sustentamos é que essas comissões, por serem órgãos do ECOSOC, traduzem melhor a política civilizatória da Assembleia Geral da ONU no tema do desenvolvimento econômico. As organizações internacionais de maior visibilidade na dimensão econômica são aquelas fruto do Acordo de Bretton Woods, o FMI, BIRD e o GATT (OMC). Essas são mais diretamente submetidas à política externa americana e aos interesses mais diretos das grandes corporações internacionais. Um elemento de apoio a essa interpretação é que as comissões, embora se alinhem às recomendações de boas práticas econômicas do mainstream do FMI, BIRD e OMC, elas incorporam temas sociais, políticos e de gênero.

De forma mais específica, o artigo tem o objetivo de chamar a atenção para a especificidade da CEPAL. Neste caso, o este artigo se desdobra de dois outros trabalhos - Almeida Filho (2003) e Almeida Filho e Corrêa (2011) - nos quais são exploradas as imposições históricas do fim da Guerra Fria e a ascensão do Neoliberalismo como ideologia hegemônica a partir dos anos 1990. Um olhar mais detido sobre as políticas recomendadas pelas comissões econômicas neste século mostra convergência em torno dos Objetivos de Desenvolvimento do Milênio (ODM) e, particularmente, em torno dos Objetivos de Desenvolvimento Sustentável (ODS). Não obstante, a CEPAL mostra resiliência em manter seu método de pesquisa - o histórico-estrutural - na elaboração 
dos diagnósticos que se sucedem nas suas publicações anuais e nos documentos bianuais apreciados pela Assembleia dos países membros.

Portanto, a principal hipótese e conclusão do artigo é que essa resiliência se sustenta nas circunstâncias históricas de criação da CEPAL e ao seu período inicial de funcionamento - anos 1940 / 1950 - no qual a comissão cumpriu funções de Escola do Pensamento. A cultura institucional acumulada neste período parece reproduzir-se, não obstante as significativas mudanças pelas quais passou a ONU desde os anos 1990. Quanto a isto, parece-nos de particular relevância e significado os documentos oficiais da comissão na década de 2010, quando a ênfase na necessidade de se superar a enorme desigualdade de renda e condições sociais presentes na região levou a instituição a afirmar que nos encontramos n“A hora da igualdade” (CEPAL, 2010).

\section{Referências Bibliográficas}

ALMEIDA FILHO, N. "O desenvolvimento da América Latina na perspectiva da CEPAL dos anos 1990: correção de rumos ou mudança de perspectiva? "In Ferraz, J. C. et al, Liberalização econômica e desenvolvimento. São Paulo: Editora Futura, 2003, pp 100-123.

ALMEIDA FILHO, N. e CORREA, V.P. A CEPAL ainda é uma escola de pensamento? Rev. Econ. Contemp., Rio de Janeiro, v. 15, n. 1, 2011, p. 92-111, jan-abr. Disponível em http://www.scielo.br/pdf/rec/v15n1/a04v15n1, acesso em 17/08/2015.

ASFOUR, E.V. International co-operation in Africa and the establishment of ECA. Civilisation, 1960.

BAMBIRRA, V. O capitalismo dependente latino-americano. Florianópolis, IELA: Editora Insular, 2012.

BIELSCHOWISKY, R. "Cinquenta anos de pensamento na CEPAL - uma resenha". In BIELSCHOWISKY, R. (org.) Cinquenta Anos do Pensamento da CEPAL. São Paulo: Ed. Record, 2000, vols. 1 e 2. Texto em espanhol (quase o mesmo) disponível em http://www.eclac.cl/publicaciones/xml/3/19373/bielchow.htm, acesso em 24/10/13.

CANO, W. Desequilíbrios regionais e concentração industrial em São Paulo - 1930 / 1970. São Paulo: UNESP, 2007.

CEPAL Transformación Productiva con Equidad. Santiago, 1990, 185p. Disponível em http://www.eclac.org/publicaciones/xml/3/4373/lcg1701e.htm , acesso 21/10/13.

CEPAL La hora de la igualdad: brechas por cerrar, caminos por abrir. Trigésimo Tercer Período de Sesiones de la CEPAL, 2010. Disponível em 
https://www.cepal.org/es/publicaciones/13309-la-hora-la-igualdad-brechas-cerrarcaminos-abrir-trigesimo-tercer-periodo

CHANG, Ha-Joon. Chutando a escada. Editora UNESP, 2004.

DOSMAN, Edgar J. The Life and Times of Raúl Prebisch, 1901-1986 . Ingram Distribution. Edição do Kindle, 2008.

ECOSOC. (documento E / 712 / Rev. 1), Item 2 da Resolução de 25 de fevereiro e 5 de março de 1948.

ECOSOC Resolução 671 (XXV), criação de uma Comissão Econômica para África, 1958.

ECOSOC Resolução 1818 (LV), Criação de uma Comissão Econômica para a Ásia Ocidental, 1973

EKPENYONG, Ekei Umo The economic commission for Africa (ECA) and development in Africa. Tese de doutorado. London School of Economics, 1989, 464p.

EWING, A. F. Foreign Trade and Economic Development in Africa by NeumarkS. Y.Stanford University, Food Research Institute, 1964. Pp. xii + 222. 56s. - Volume 3 Issue 3.

FURTADO, C. Formação econômica da América Latina. Rio de Janeiro: Lia Editora, 1969.

FURTADO, C. A comissão econômica para a América Latina, 1988. Reproduzido In D’Aguiar, Rosa Freire (org.) Essencial Celso Furtado. São Paulo: Pinguin Classics / Companhia das Letras, 2013.

FURTADO, C. Formação econômica do Brasil. 32 . Edição. São Paulo: Companhia Editora Nacional, 2005 [1959].

GONÇALVES, Luiz Eduardo Fonseca De Carvalho As Relações Brasil-CEPAL (19471964). Dissertação de Mestrado, Instituto Rio Branco, Função Alexandre de Gusmão, 2011.

HOBSBAWM, E. A era dos extremos. Nova lorque: Penguin Group, 1994.

HUNT, D. Economic Theories of Development: An Analysis of Competing Paradigms. London: Harvest Wheatsheaf, 1989.

JUDT, T. Pós-Guerra - uma história da Europa desde 1945. Rio de Janeiro: Objetiva, 2007.

LOPES, Tiago Camarinha; ALMEIDA FILHO, N.; PINTO, G. L.H. Prebisch, Furtado e a Revolução Cubana. Estudios Latinoamericanos UNAM, v. 42, 2018, p. 17-34. Disponível em https://www.researchgate.net/publication/329625619_Prebisch_Furtado_e_a_Revolu 448 
cao_Cubana_Prebisch_Furtado_y_la_Revolucion_Cubana_Prebisch_Furtado_and_t he_Cuban_Revolution. Acesso em 31/07/2019.

MURPHY, Craig Organização internacional e mudança industrial - governança global desde 1850. Editora UNESP, 2014.

PREBISCH, R. Estudo Econômico da América Latina. In BIELSCHOWSKY, R. Cinqüenta Anos de Pensamento da CEPAL. Op.cit. vol. 1, 2000 [1949], pp 137-178.

REINERT, ERIK. S. Como os países ricos ficaram ricos ... e porque os países pobres continuam pobres. Rio de Janeiro: Contraponto, 2016.

ROCHA, João Manuel África: ano que começou um futuro ainda por cumprir. 2010. Disponível em https://www.publico.pt/2010/02/13/mundo/noticia/africa-o-ano-em-quecomecou-um-futuro-ainda-por-cumprir-1422629, acesso em 04/04/2018.

RODRIGUEZ, O. O Estruturalismo Latino-americano. Rio de Janeiro: Civilização Brasileira, 2009.

ROSTOW, W. Etapas do desenvolvimento econômico. Rio de Janeiro: Zahar, 1961.

SUZIGAN, W. Indústria brasileira: origem e desenvolvimento. São Paulo: Braziliense, 1986.

THORP, Rosemary Progreso, pobreza y exclusión: una historia económica de América Latina en el siglo XX. Banco Interamericano De Desarrollo Union Europea, 1998.

UNECE History, 2020. http://www.unece.org/oes/history/history.html , acesso em 19/02/2020.

Recebido em: 05/09/2019

Aprovado em: 17/02/2020 